\title{
KNOWLEDGE CONVERSION: AN EVALUATION OF BPPT KM APPLICATION UTILIZATION AS A KNOWLEDGE MANAGEMENT SYSTEM
}

\author{
Ria Ariani*, \& Nur Sanny Rahmawati** \\ *Pusat Manajemen Informasi - Badan Pengkajian dan Penerapan Teknologi \\ **Universitas Indonesia \\ Email: ria.ariani@bppt.go.id,nur.sanny@menpan.go.id
}

DOI: $10.24252 /$ kah.v8cf1

\begin{abstract}
ABSTRAK: Artikel ini memaparkan bagaimana pengetahuan dikonversi melalui aplikasi manajemen pengetahuan yang disebut BPPT KM App yang dikelola oleh Pusat Manajemen Informasi - Badan Pengkajian dan Penerapan Teknologi, dan fungsinya digunakan sebagai sistem manajemen pengetahuan. Tujuan penulisan artikel ini adalah untuk menjelaskan implementasi konversi pengetahuan di Badan Pengkajian dan Penerapan Teknologi dan untuk mengetahui cara kerja sistem manajemen pengetahuan dan efektivitas aplikasi. Metode kualitatif digunakan dengan pendekatan observasi partisipatif dan review-narative. Dengan pendekatan tersebut, peneliti melakukan investigasi langsung ke subjek penelitian dan terlibat dalam proses konversi pengetahuan aplikasi. Hasil penelitian menunjukkan bahwa konversi pengetahuan dapat dilakukan oleh pegawai BPPT baik pegawai yang berada di MH Thamrin Jakarta maupun Puspiptek Serpong dan indikator SECI telah dilakukan dalam sistem manajemen pengetahuan melalui aplikasi. Dapat disimpulkan bahwa Aplikasi BPPT KM telah memfasilitasi implementasi konversi pengetahuan kepada seluruh pegawai BPPT secara jauh dan dapat diakses kapan pun dan di mana pun, terutama dalam situasi pandemi ini.
\end{abstract}

Kata kunci: Konversi pengetahuan; Manajemen pengetahuan

ABSTRACT: This paper presents how knowledge being converted through a knowledge management application called BPPT KM App that is managed by Pusat Manajemen Informasi Badan Pengkajian dan Penerapan Teknologi, and its function used as a knowledge management system. The purpose of this paper is to explain the implementation of knowledge conversion in Badan Pengkajian dan Penerapan Teknologi and to know how the knowledge management system works and the effectiveness of the app. The method used in this paper is qualitative with a participative observation approach and narrative review. With these approaches, researchers do the direct investigation of the subject research and involved in the process of knowledge conversion of the app. The result of this study shows that knowledge conversion can be implemented by BPPT employees, whether the employees located in MH Thamrin Jakarta or Puspiptek Serpong, and the SECI indicators have been conducted in the knowledge management system through the app. It can be concluded that BPPT KM App has facilitated knowledge conversion implementation to all BPPT employees remotely and it can be accessed anytime and anywhere, especially in this pandemic situation.

Keywords: Knowledge conversion; Knowledge management system

\section{INTRODUCTION}

Knowledge is an essential asset in an organization. Knowledge is everything that can be known, intelligence, or anything which is known that is related to a specific matter (Kamus Besar Bahasa Indonesia, 2007). Organizational knowledge may come from employee quality of thought that includes ideas focused on the organizational day-to-day activity (Polanyi, 1966). Knowledge processes were divided into two forms of knowledge that are tacit and explicit 
(Nonaka and Takeuchi, 1996; Huang and Wang, 2002). Tacit or implicit knowledge is the knowledge that has been stored in individual minds but it is not explicitly expressed so that it cannot be understood by other individuals (Collins, 2010). Meanwhile, Kementerian Pendayagunaan Aparatur Negara dan Reformasi Birokrasi (2011) mentioned that explicit knowledge is all information represented in the organization and made it accessible to all organization members. This statement also supports Polanyi (1966) who said that explicit knowledge should be rendered clear, explicitly stated and visible. Therefore, the process of knowledge conversion can be implemented in every organization.

Theoretically, knowledge conversion cannot be apart from knowledge management itself. It can be a model to analyze how the knowledge management process works. Tseng (2010) describes the definition of knowledge conversion as a knowledge transformation process where tacit knowledge can be reformed to explicit knowledge and vice versa which contradicts Polanyi's statement (1966), "all knowledge is rooted in tacit knowledge". The components of knowledge conversion are widely known as SECI (socialization, externalization, combination, and internalization). Those four components can be utilized to know how far knowledge has been managed in the organization.

Badan Pengkajian dan Penerapan Teknologi (BPPT), Agency for the Assessment and Application of Technology, as an institution that works in the field of technology innovation and provides services based on technology, information and communication, needs to aware of organizational knowledge management in order to make a right decision for the organization. The knowledge that is managed in an organization could be from employee's ideas and experiences and it can be created through employee discussions. Consequently, Badan Pengkajian dan Penerapan Teknologi (BPPT) develops a system for managing some of the organizational knowledge which comes from the minds of employees and can be managed remotely such as finishing job tasks and brainstorming project ideas. This consideration certainly has enormous benefits in the process of managing organizational knowledge and all the knowledge conversion, especially in this pandemic situation where direct interaction is quite limited.

Several studies related to knowledge conversion and knowledge management systems have been conducted both in Indonesia and internationally. Ariq, Yani dan Sri (2020) have analyzed the knowledge management system based on hydroponic aquaculture web with knowledge management cycle. In their study, the process of knowledge conversion worked from tacit to explicit using a knowledge management system life cycle (KMSLC) method. Besides, Karto et. al. (2017) also discussed a comparison between several results in the field of the knowledge management system and the conclusion showed that the development of knowledge management systems in big data era or in the future must be balanced with the development of capabilities and its features. Additionally, in Sukmawati, et. al. (2010) knowledge conversion is more emphasized on the knowledge usage process, both tacit and explicit, as a strategy to encourage business innovation in a daily small enterprise.

At this point, the authors aim to explain the processes of the knowledge conversion in Badan Pengkajian dan Penerapan Teknologi (BPPT) and to know the effectiveness of the knowledge management system from BPPT knowledge management application. As expected, this paper would provide an extensive overview of the knowledge conversion that occurred in Badan Pengkajian dan Penerapan Teknologi (BPPT). Besides, this research is also to provide an overview of the connection between employee activities and knowledge conversion in the knowledge management application with SECI indicators.

\section{LITERATURES REVIEW}

\section{Knowledge Conversion}

Knowledge conversion is a branch of knowledge management. It has been known through several works of literature that define that knowledge management is a management process related to people with their uniqueness, expertise, and experiences (Nonaka in Yusup, 2012). Tjakraatmadja (2006) said that knowledge management is influenced by a good working culture 
whether vertical or horizontal (among co-workers). Then, knowledge management can be systematic steps on how knowledge is organized starting with sharing experiences and discussion results in an organization.

In the beginning, the concept of knowledge conversion was stated by Nonaka and Takeuchi (1995). Furthermore, knowledge conversion is used as an analysis model that combines both tacit and explicit knowledge. There is a well-known knowledge conversion model namely SECI (Socialization, Externalization, Combination, and Internalization) (Nonaka dan Takeuchi in Gourlay, 2003), with steps as follow:

1) First stage - Socialization

Socialization is a knowledge conversion process where tacit knowledge (knowledge that is in individual minds) is reformed to tacit knowledge as well but in a more advanced way (Priambada, 2010).

2) Second Stage- Externalization

Externalization is a knowledge conversion process where tacit knowledge changed into explicit knowledge (Priambada, 2010).

3) Third Stage - Combination

Combination is a continuation of the externalization process where explicit knowledge (knowledge that has been documented) is converted to explicit knowledge (Priambada, 2010).

4) Fourth Stage - Internalization

Internalization is a knowledge conversion process where the new explicit knowledge can be tacit knowledge for individuals who receive it (Priambada, 2010).

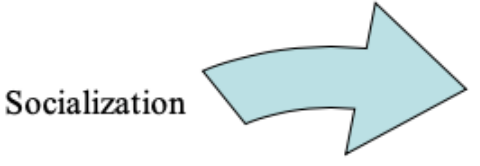

Externalization
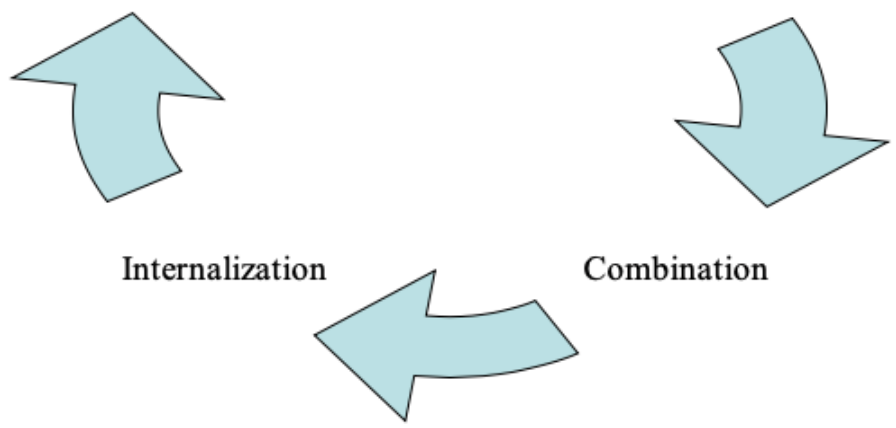

Figure 1. Knowledge Conversion: SECI Model

\section{Knowledge Management System}

Knowledge Management System (KMS) is a collection of strategies and practices to analyze, to organize, to distribute, to maintain, and to share knowledge from the experiences of an organization (Alavi, 2001). Additionally, Ahlawat (in Subagdja, 2011) defined knowledge management system as a modern information technology utilization for systemization in the purpose to increase and accelerate knowledge management within an organization. King dan Marks Jr. (2008) also mentioned that knowledge management system is intended to support 
knowledge sharing in an organization so that knowledge dissemination can be delivered to wider audiences.

There are the main objectives of KMS (Davenport et. al. in Fahmi, 2013), as follows:

1) Creating Knowledge

Knowledge was created when people doing a specific activity. External knowledge sometimes being brought to the organization by people who are working on it.

2) Capturing Knowledge

Knowledge was identified and represented as a logical value in a logical way.

3) Collaborating Knowledge

New knowledge can be placed in a context where it can be continued with another knowledge.

4) Storing knowledge

Useful knowledge can be stored so that other individuals in the organization can access it when it is needed.

5) Processing knowledge

Knowledge should be kept updated along with its relevancy and accuracy.

6) Disseminating knowledge

Knowledge should be disseminated and available in a proper format then it can be accessed anytime and anywhere by employees in an organization.

\section{Ten-Step Knowledge Management Roadmap}

In a knowledge conversion process, specifically to the knowledge management system part, it can be quite complicated. Thus, all the stages in knowledge conversion, which is part of the knowledge management system, need to be known started by knowledge planning until its evaluation. The 10-Step Knowledge Management Roadmap is giving a clear direction and can be utilized to analyze a knowledge management system. This theory is stated by Amrit Tiwana (1999). Amrit described phases of the 10-Step Knowledge Management Roadmap as follows:

1) Infrastructure evaluation

This phase covers the activity of analyzing the infrastructure and cooperates it with business processes and knowledge management processes.

2) System analysis, design, and system development

At this second phase, Knowledge management infrastructure is designed, all assets and systems are audited and the knowledge management system is developed.

3) Deployment system

The third phase consists of deploying activity with a method of result-driven incremental where change, culture, and reward structure are managed.

4) Evaluation

In the last phase, system performance is evaluated and returned on investment (ROI) is measured. 


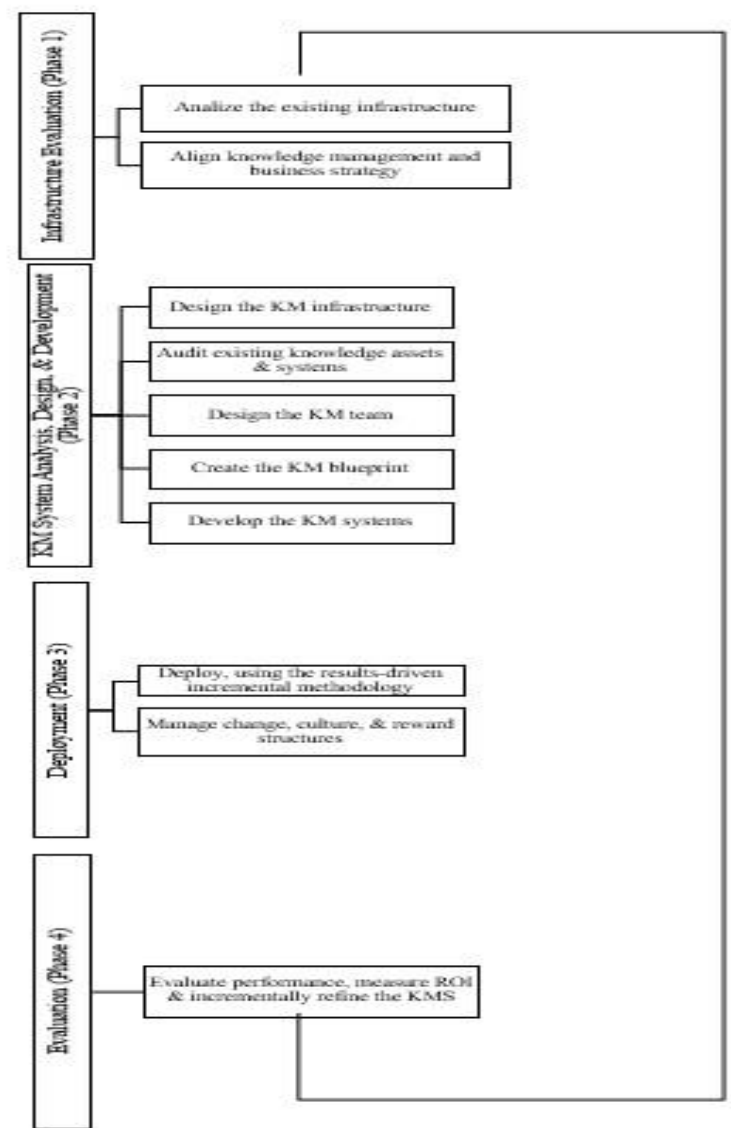

Figure 2. The 10-Step Knowledge Management Roadmap

\section{METHODS}

This study uses a qualitative method with a participatory observation approach and narrative review. Qualitative research concerns the facts that can be put and can be seen by a person, whether as a researcher or an object of research - a subjective construction (Pendit in Rahmawati, 2016). A participatory observation approach is an approach where a researcher is involved in the activities of the research object investigated and it is used as a source of research (Sugiyono, 2017). In participatory observation, a researcher sees what is done related to the research object, hears what people say, and is involved in the conduct of what people do (Susan Stainback in Sugiyono, 2017). Besides, Middleton (2012) stated that narrative review is needed to gain a comprehensive understanding related to the research topic, in this case, is a knowledge management system, knowledge conversion, knowledge management, and effectiveness of knowledge management system used in the organization. The analysis technique used is descriptive content analysis. This technique is considered suitable for the research topic because it describes research content which is investigated by analyzing knowledge management system phenomenon utilized in BPPT using related works of literature (Vaismoradi, Turunen, dan Bondas, 2013). Also, a narrative review is conducted with the works of literature on the topic of knowledge conversion and knowledge management systems so that a theoretical foundation can be built to support the research topic.

\section{RESULTS AND DISCUSSION}

\section{Content Analysis BPPT KM App}

Application of Knowledge Management (KM) BPPT is a tool for managing BPPT intellectual assets to give easiness for employees in order to acquire knowledge, share knowledge, discuss and collaborate among other employees. It is also to encourage and improve 
innovation of technology in the organization, and to assist BPPT stakeholders in the process of decision making so it can be done effectively and efficiently. The concept of this app came from BPPT Chairman himself to monitor and to track down all the projects and the work results done by all BPPT employees in a top to down-level hierarchy. For example, staff can be monitored by the head of subdivision, then the head of the working unit can also monitor all head of divisions and sub-divisions under him. Additionally, using this app BPPT Chairman can monitor the work that is taking place and can give direct instruction to the required employee.

This BPPT KM Application was built with the objectives of ensuring the effectivity BPPT knowledge management processes, both tacit and explicit, to create a supportive environment as a learning organization so that each employees being able to adapt the environmental changes quickly and can encourage the creation of competitive technological innovations by benefitting all functionality and data that is made available in the app. All knowledge stored in BPPT KM Application can be accessed via https://km.bppt.go.id. Additionally, BPPT KM App can be accessed through mobile phone by downloading the application first, whether in Playstore for Android and Appstore for iPhone. Each knowledge conversion described in the SECI model is hoped to be implemented and applied in BPPT KM application and it is provided through all features available in the BPPT KM application. All knowledge management system (KMS) processes at BPPT can be illustrated in Figure 3 below:

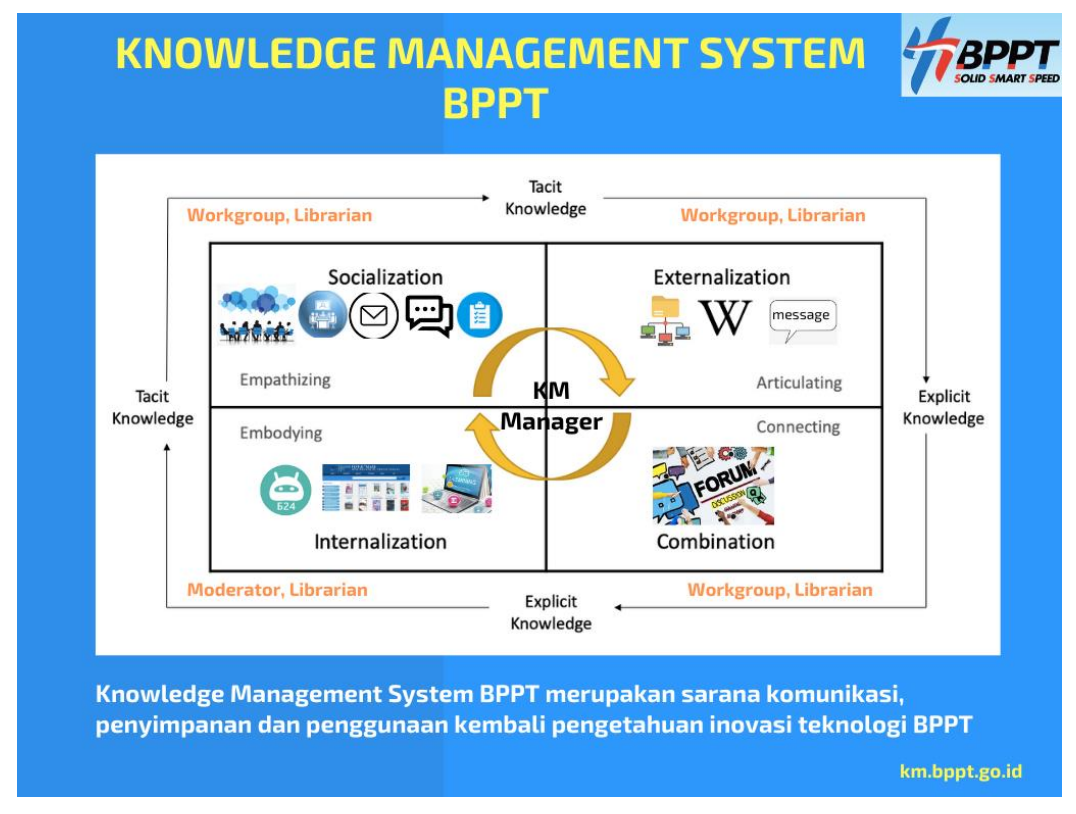

Figure 3. SECI flow in BPPT Knowledge Management System

The features in the app were created to support the implementation of knowledge management and knowledge conversion at BPPT. They are as follows:

\section{Task Feature}

The Task Feature is to manage all employee tasks in their daily routines and the project activities can be observed directly by their supervisors at BPPT. The display of Task Feature can be seen in Figure 4 . 


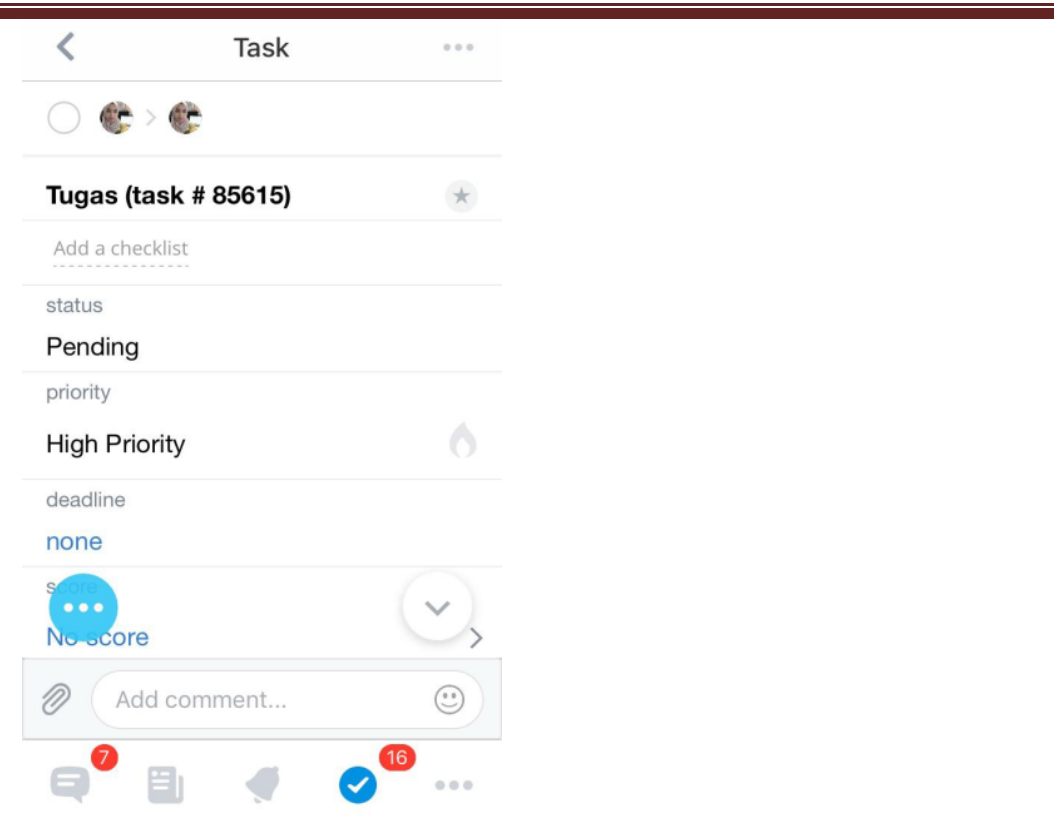

Figure 4. Task Feature at BPPT KM Application

In this feature, a supervisor at BPPT in the level of echelon 1 , echelon 2 , echelon 3 , and echelon 4 can delegate a task to the employees under their division to be completed. All notifications of the tasks will automatically appear at the BPPT KM application on the mobile phone and employees who receive the assignments. So, they can directly start to work. The supervisors can also monitor the process of the task conduction whether if it has been finished or not.

\section{Clock-in and Clock-out Feature}

The Clock-in and Clock-out feature in BPPT KM application is a tool made to replace the manual presence system in BPPT where all employees' attendance is directly counted and recorded in the application. This feature was developed to create a function of working time management where employees can present their attendances when they arrive at the office and when they are going to leave. Figure 5 and Figure 6 show the interface of the Clock-in and Clock-out feature in BPPT KM application.

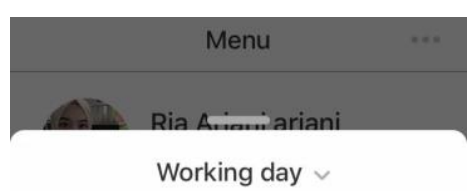

Working day

WORKING DAY DURATION

\section{0:00:00}

CLOCK IN

Figure 5. Clock-in feature at BPPT KM Application 

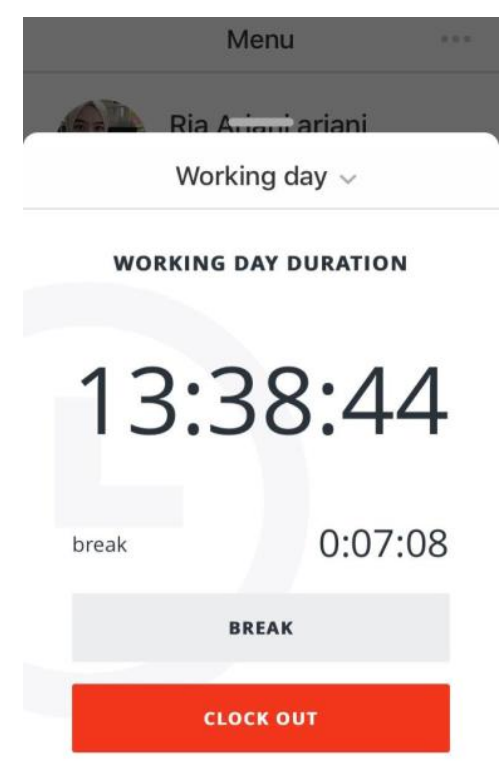

Figure 6. Clock-out feature at BPPT KM Application

\section{Activity Stream Feature}

This feature shows all activities and tasks that happen at BPPT KM application just like 'news feeds' on Facebook. From this menu, all employees can directly interact, collaborate, and share data with other employees. As can be seen in Figure 7.

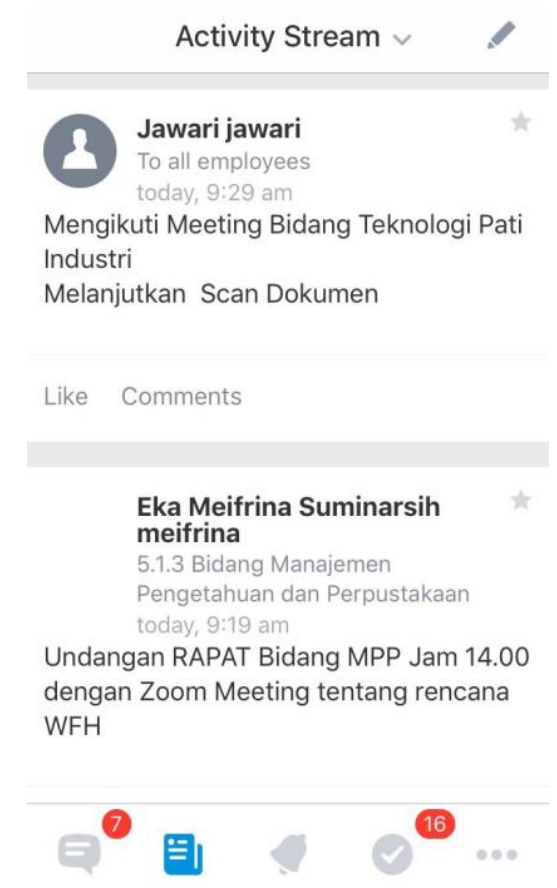

Figure 7. Activity Stream Feature at BPPT KM Application

\section{Calendar}

In the application, the Calendar feature is utilized as an agenda where the employees can set a schedule of daily activities or meetings, and it can include other employees and working units in BPPT. At this feature, some participants who are involved in the activity can be arranged 
and a reminder can be notified to remind all the participants regarding the agenda or the activity. As can be seen in Figure 8.

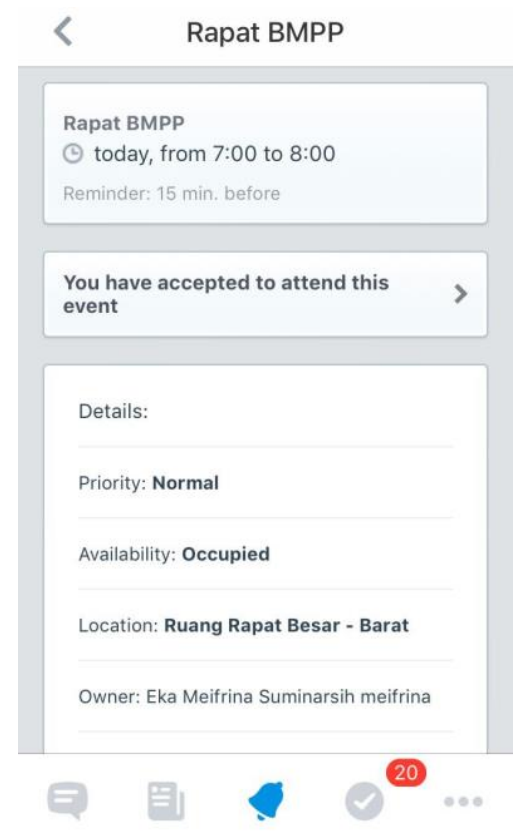

Figure 8. Calendar feature at BPPT KM application

\section{Drive}

The Drive feature at BPPT KM application functioned as a storage or a container for managing all documents or files which are available at BPPT KM application. In this feature, files and documents can be saved, communal edited, and shared via internal links or shared publicly. The Drive feature was created as file storage for storing all employee files and documentation. As shown in Figure 9.

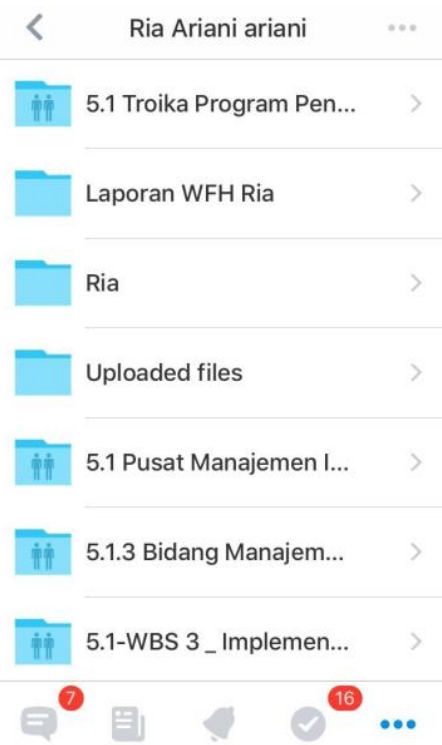

Figure 9. Drive feature at BPPT KM Application 


\section{Chats}

This feature is a tool provided in the application for BPPT employees to communicate and discuss with other employees. It can be done by chatting or video call to other employees in BPPT. A video call can participate with a maximum of four users. Examples of chat feature displays can be seen in Figure 10.

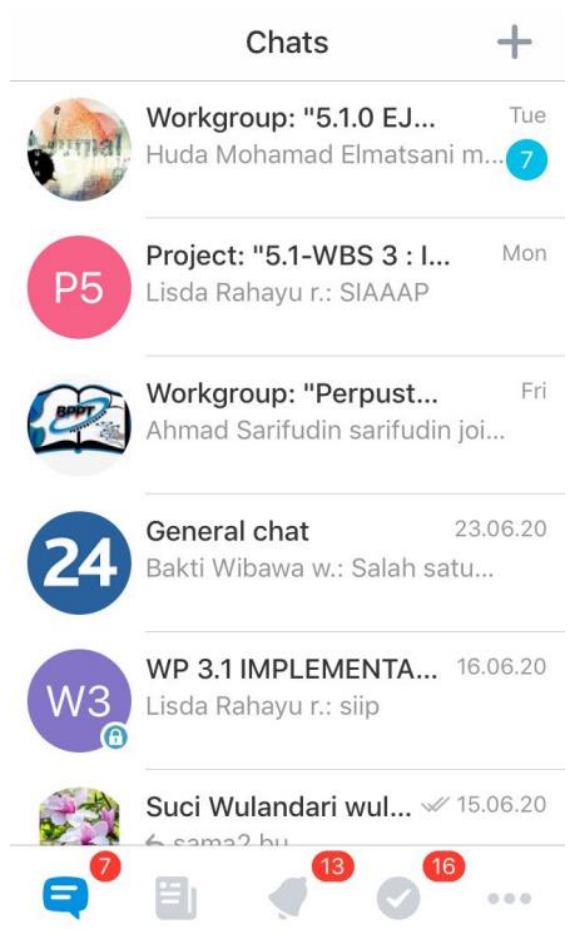

Figure 10. Chats feature at BPPT KM application

\section{Notifications}

In BPPT KM application, there is also a notifications feature, where each employee will be able to know if there is any task given by supervisors or if there is any invitation of meetings or activities and the notifications will appear on BPPT employee's mobile phone right away through the BPPT KM Application. Figure 11 shows the display of the notifications features at BPPT KM application. 


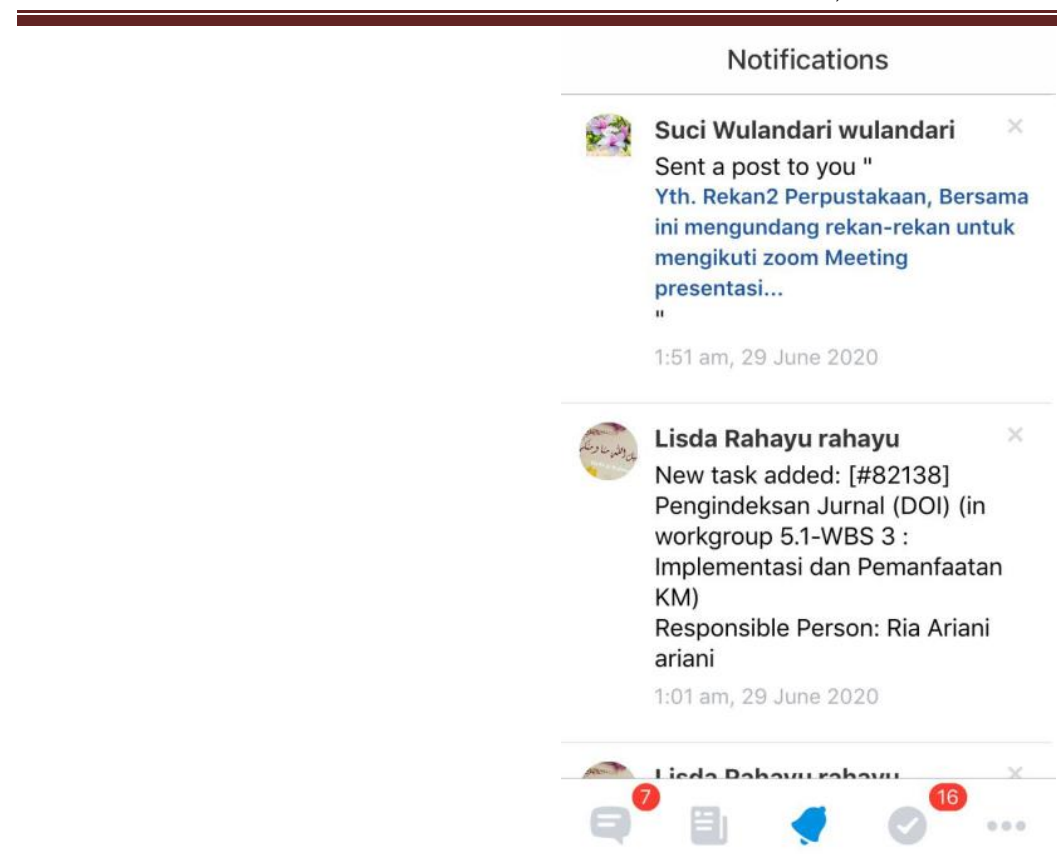

Figure 11. Notifications feature at BPPT KM Application

Furthermore, through its features, BPPT KM application is expected to make everything easier for all BPPT employees in order to manage their knowledge. As it is explained in Fitriasmi (2010) that if the system is getting better then there is no doubt that more people will use it. Hence, there is a positive correlation between the BPPT KM Application and the output where BPPT intellectual assets being managed in this KM application. Supported by a good quality system, BPPT KM application is hoped to be able to solve the needs of the organization and can solve institutional problems.

\section{Evaluation and Knowledge Conversion in BPPT KM Application}

\section{a. Knowledge evaluation in BPPT KM Application}

BPPT KM Application is a mobile-based application developed to support document management and engineering activities that are conducted at BPPT. It was supplemented with file sharing, so all employees can exchange files, documents, and data. Utilization of knowledge management system through BPPT KM application has been running since the beginning of 2020 and has been socialized to more than 20 (twenty) technical working units in BPPT.

In the beginning, BPPT Knowledge Management (KM) application was originated from the idea of developing the old system of BPPT knowledge management portal which can be accessed via https://kms.bppt.go.id. The concept of the old BPPT knowledge management system portal is actually a combination of several services managed by Bidang Manajemen Pengetahuan dan Perpustakaan-Pusat Manajemen Informasi BPPT (Knowledge Management and Libraries BPPT Information Management Center), which include: Digital Library BPPT (digilib.bppt.go.id), Expertise System BPPT, BPPT Press and BPPT Electronic Journal (ejurnal.bppt.go.id). However, this portal is lack of interactivity with BPPT employees, so the development of the second BPPT knowledge management system was initiated and it can be accessed through km.bppt.go.id.

BPPT KM Application is originally serviced by an outsourcing service from Bitrix 24 . The type of platform used is for communication, collaboration, and management of company assets. The facilities given from BPPT KM application features can also be connected with another platform such as Googledocs, for example in the use of editing collaboration. To activate this application it should be connected to BPPT employee intranet username and password using the LDAP (Lightweight Directory Access Protocol). After that, the BPPT KM Application can be utilized during the internet network both inside and outside the BPPT area. In terms of security, 
BPPT KM application server has been secured. The application itself can be downloaded via the Appstore and Playstore for mobile use.

From the perspective of business process, BPPT KM Application is expected to provide easiness in finding, sharing, discussing, and collaborating amongst BPPT employees so that it can improve technological innovation within the institution. It can also assist BPPT leaders in making decisions appropriately and quickly by utilizing the menus available in the application. However, aside from its development, there are some limitations in using BPPT KM application as figured out in Table 1 below.

Table 1. Business processes and limitations

\begin{tabular}{llll}
\hline \multicolumn{1}{c}{ Business Process } & \multicolumn{1}{c}{ Strength } & \multicolumn{1}{c}{ Weakness } \\
\hline 1) Login to App & $\begin{array}{l}\text { Secure } \begin{array}{c}\text { (using internal } \\
\text { username and password) } \\
\text { Variety of features to support } \\
\text { work management } \\
\text { Easy navigation }\end{array} \\
\text { Selecting the features }\end{array}$ & $\begin{array}{l}\text { Closed Access (data could not be seen } \\
\text { by anternal party) } \\
\text { Runing only under internet } \\
\text { connection } \\
\text { Many optional tools, users need the } \\
\text { guideline on how to do it } \\
\text { Could not involve external user }\end{array}$ \\
$\begin{array}{l}\text { 4) Adding the files } \\
\text { in the features }\end{array}$ & $\begin{array}{l}\text { Easy selection } \\
\text { Activities notifications up notifications in the }\end{array}$ & $\begin{array}{l}\text { Each activity will be notified (alert } \\
\text { abundance) }\end{array}$ \\
\hline
\end{tabular}

\section{b. Knowledge Conversion in BPPT KM Application}

The main elements of BPPT KM Application are document management, chat, and community of practices. The early reason for implementing KM Application in BPPT is to make it better in identifying which knowledge should be treated by BPPT working units and to identify the specific expertise that belongs to a specific individual in BPPT. Zhou and Fink (2017) mentioned that it is vital for an organization to encourage and develop the knowledge of its employees or its members. Conversely, organizations also need to create an environment that encourages an active sharing knowledge culture and it can monitor the management of knowledge that happens in a system, specifically the knowledge management system.

Knowledge conversion has worked in the app and we can look at each feature in KM app that represents the SECI Model, as follows:

Table 2. Categorization of KM App Features in SECI Model

\begin{tabular}{|l|l|c|}
\hline \multicolumn{1}{|c|}{ Features } & \multicolumn{1}{|c|}{ Characteristics } & Modes of Conversion \\
\hline Task & $\begin{array}{l}\text { Documenting problems and } \\
\text { working solutions. }\end{array}$ & From tacit to explicit \\
\hline $\begin{array}{l}\text { Working time } \\
\text { management (clock-in } \\
\text { and clock-out) }\end{array}$ & $\begin{array}{l}\text { Documenting the value of all } \\
\text { personal individual } \\
\text { knowledge, then it becomes } \\
\text { value of organizational } \\
\text { knowledge. }\end{array}$ & From explicit to explicit \\
\hline Activity stream & $\begin{array}{l}\text { Documenting all employee } \\
\text { dialogues }\end{array}$ & From tacit to explicit \\
\hline Calendar & $\begin{array}{l}\text { Documenting all working } \\
\text { schedules within } \\
\text { organization. }\end{array}$ & From explicit to explicit \\
\hline Drive & $\begin{array}{l}\text { Combining all working } \\
\text { documents and procedures } \\
\text { then it becomes value of } \\
\text { organizational knowledge. }\end{array}$ & $\begin{array}{l}\text { Sharing and accummulating } \\
\text { all tacit knowledge within } \\
\text { organization. }\end{array}$ \\
\hline Chats &
\end{tabular}


Based on Table 2, it can be said that the features in BPPT KM application encourage and facilitate the occurrence of knowledge conversion as it was described by Nonaka and Takeuchi (in Gourlay, 2003) and it supports the SECI theory which includes Socialization, Externalization, Combination, and Internalization. From all seven features in the application, six features represent at least one of the knowledge conversion aspects in SECI. The six features that reflect knowledge conversion activities are task features, working time management (clock-in and clock-out), activity stream, calendar, drive, and chats.

The socialization aspect can be supported by a chat feature where ideas can be used by other employees and it could be a new idea that will help them in conducting their work and encourage the creation of innovation. Andrawina (2012) defined the socialization as transfer of knowledge processing from tacit to tacit. She added that knowledge keeps strolling around within the organization as in the feature chats all employees can stimulate other ideas.

The second conversion form of SECI is externalization. It can be found in the feature of tasks, activity streams, and calendar. According to Nugraha (2015) that it is a documentation process that shaped tacit knowledge in the form of a document so that others can see, read, and learn from it. All tasks were given to employees via the feature tasks, then the proof of the work is submitted to the app so that the supervisor can directly evaluate and read it. This feature has represented the element of externalization. The same characteristic can also be seen in the feature of activity stream and calendar, where employees' dialogues and schedules are documented in the app.

Feature drive represents the stage of combination where the mode of knowledge conversion from explicit-to-explicit knowledge. In this aspect, all working documentation and procedures are combined and it brings value for the organization, in this case, is BPPT. Andrawina (2012) stated that combining individual knowledge is important in the combination stage and it can be used as organizational best practice and stakeholders can also analyze which best practices offer the best organizational knowledge.

Zhou and Fink (2017) stated that a knowledge management system along with advanced technology can be a way for increasing the value and competitiveness of organizations. A good knowledge management framework is the one that could lead organizations in creating a systematic work system.

\section{CONCLUSION}

Overall, the BPPT KM Application is reliable and it has brought benefits for employees to support their work activities. It can also be concluded that knowledge conversion has been implemented appropriately in the aspects of SECI, defined by Nonaka and Takeuci (1996). The features contained in KM application that can support the conduct of knowledge management in stages of SECI model are task, working time management (clock-in and clock-out), activity stream, calendar, drive, and chats

All features and business processes in BPPT KM application also support the implementation of knowledge conversion that is represented in the system. Furthermore, for future research recommendations, it is important to know how institutional regulations play a role in the implementation of knowledge management system application in BPPT, so a more comprehensive and in-depth understanding related to knowledge management aspects can be provided

\section{REFERENCES}

Alavi M, dan Leidner DE. (2001). Knowledge Management and Knowledge Systems: Conceptual Foundations and Research Issue. MIS Quarterly, Vol. 25(1), pp. 107-136.

Ariq, C. W., Nurhadryani, Y, \& Wahyuni, S. (2020). Knowledge Management System Berbasis Web tentang Budidaya Hidroponik untuk Mendukung Smart Society. Jurnal Teknologi 
Informasi dan Ilmu Komputer (JTIIK), Vol. 7(3), Pp. 619-628. Diakses Melalui http://jtiik.ub.ac.id/index.php/jtiik/article/view/2200/pdf pada 17 Juni 2020.

Collins, H. (2010). Tacit and Explicit Knowledge. Chicago: The University of Chicago Press.

Fahmi, A. (2013). Kajian Pengembangan Knowledge Management System (KMS) untuk Litbang Kedirgantaraan pada Lembaga Penerbangan dan Antariksa Nasional (LAPAN). Berita Dirgantara, Vol. 14(1), pp. 17-24. Diakses melalui http://jurnal.lapan.go.id/index.php/berita_dirgantara/article/view/2061 pada 18 Juni 2020.

Fitriasmi, S. M. (2010). Evaluasi Kesuksesan Aplikasi Knowledge Management dalam Organisasi. Jurnal Dinamika Manajemen, 1 (1), pp. 18-26, https://journal.unnes.ac.id/nju/index.php/jdm/article/view/2444

Gourlay, S. (2003). The SECI Model of Knowledge Craetion: Some Empirical Shortcomings. Diakses melalui http://eprints.kingston.ac.uk/2291/1/gourlay\%202004\%20seci.pdf , pada 18 Juni 2020.

Indonesia. (2011). Peraturan Menteri PANRB Nomor 14 tahun 2011 tentang Pedoman Pelaksanaan Program Manajemen Pengetahuan (Knowledge Management). Jakarta: Kementerian PANRB.

Kamus Besar Bahasa Indonesia. (2007). Jakarta: Balai Pustaka.

Karto, I., Jambak, M. I., Kosala, R., \& Prabowo, H. (2017). Current Issue on Knowledge Management System for Future Research: A Systematic Literature Review. International Conference on Computer Science and Computational Intelligence (ICCSCI 2017). Diakses melalui

https://www.researchgate.net/publication/320396848_Current_Issue_on_Knowledge_M anagement_System_for_future_research_a_Systematic_Literature_Review pada 16 Juni 2020

King, W. R., \& Peter, M. Jr. (2008). Motivating knowledge sharing through a knowledge management system. Omega, 2008, 36 (1), February 2008, pp. 131-146, https://doi.org/10.1016/j.omega.2005.10.006

Nonaka, I., \& Takeuchi, H. (1995). The Knowledge-Creating Company: How Japanese Companies Create the Dynamic of Innovation. New York: Oxford University Press.

Nonaka, I., \& Nishiguchi, T. (2001). Knowledge Emergence: Social, Technical, and Evolutionary Dimensions of Knowledge Creation. New York: Oxford University Press.

Middleton, P. M. (2012). Practical use of the Glasgow Coma Scale; a comprehensive narrative review of GCS methodology. Australasian Emergency Nursing Journal, 15 (3), pp. 170183, https://doi.org/10.1016/j.aenj.2012.06.002

Priambada, D. B. (2010). Implementasi Knowledge Management System di Perusahaan. Bogor: Institut Pertanian Bogor. Diakses dari https://www.scribd.com/doc/28192137/Implementasi-Knowledge-ManagementSystem-di-Perusahaan

Rahmawati, N. S. (2016). Berbagi Pengetahuan: Representasi dalam Novel Paper Heart. Depok: Universitas Indonesia.

Subagja, S. (2011). Perancangan Knowledge Manajement System Untuk Pelaanan Perizinan Terpadu Satu Pintu. Konferensi Teknologi Informasi dan Komunikasi untuk Indonesia. 14-15 Juni 2011. Bandung

Sugiyono. (2017). Metode Penelitian Kuantitatif, Kualitatif, dan R\&D. Bandung: Alfabeta.

Sukmawati, A., M.S. Ma'arif, Marimin, H. Hardjomidjojo, dan N.S. Indrasti. (2010). Model Kontribusi Aset Pengetahuan dalam Memfasilitasi Proses Penciptaan Pengetahuan pada Koperasi Susu. Jurnal Manajemen dan Organisasi, Vol. 1(1). Diakses melalui http://journal.ipb.ac.id/index.php/jmo/article/download/14150/10544 pada 15 Juni 2020.

Tiwana, A. (1999). The Knowledge Management Toolkid: Practical Technique for Building a Knowledge Management System. London: Prentice-Hall, Inc.

Tjakraatmadja, J. H., \& Lantu, D. C. (2006). Knowledge Management dalam Konteks Organisasi Pembelajar. Bandung: SBM-ITB. 
Tseng, S. (2010). The correlation between organizational culture and knowledge conversion on corporate performance. Journal of Knowledge Management, Vol. 14 No. 2, pp. 269-284. https://doi.org/10.1108/13673271011032409

Vaismoradi, M., Turunen, H. and Bondas, T. (2013), Qualitative descriptive study. Nurs Health Sci, 15, pp. 398-405, doi:10.1111/nhs.12048

Venkatraman, S. and Venkatraman, R. (2018). Communities of Practice Approach for Knowledge Management Systems. Systems, 6(4), 36, https://doi.org/10.3390/systems6040036

Yusup M., Pawit. (2012). Perspektif Manajemen Pengetahuan Informasi, Komunikasi, Pendidikan, dan Perpustakaan. Jakarta: Rajawali Pers.

Zhou, A. Z., \& Fink, D. (2003). Knowledge management and intellectual capital: an empirical examination of current practice in Australia, Knowledge Management Research \& Practice, 1:2, 86-94, DOI: 10.1057/palgrave.kmrp.8500009 